Key biotechnology patent delayed

\section{Cohen-Boyer patents could face challenge}

\section{Washington}

The US Patent and Trademark Office suddenly announced on 30 June that it was delaying the issue of a second fundamental patent on genetic engineering to Stanford University and the University of California. The patent, which complements the Cohen-Boyer patent issued to the universities in December 1980, had already been assigned a patent number and was scheduled for issue on 13 July.

The announcement immediately sparked off speculation that a challenge to the patents was imminent. That speculation was fuelled by the revelation that an Exxon patent attorney, Albert Halluin, had discovered several potential defects in the original patent. Halluin's findings are to appear in a book called The Patenting of Life Forms, to be published by Cold Spring Harbor Laboratory on 15 August.

The most potentially damaging of Halluin's observations is that since the original patent was filed by Dr Stanley Cohen of Stanford and Dr Herbert Boyer of the University of California, San Francisco in November 1974, new findings have invalidated some of the information supplied in the patent specifications. The patent covers a key plasmid which is used as the vehicle for inserting new genes into the bacterium Escherichia coli and describes the method for producing this plasmid. But in 1977, Dr Cohen published a paper in Journal of Bacteriology that admits an error in the original procedure. A number of molecular geneticists have asserted that the error was substantial enough to make it impossible to duplicate Cohen's and Boyer's work from the patent description alone.

Halluin argues that deposition of the product in the American Type Culture Collection can get around such problems, but - and this is a second potential flaw in the patent - Cohen and Boyer did not deposit their plasmid until June 1981, more than six months after the patent was issued.

A third possible defect in the original patent concerns prior disclosure. A patent is not granted if information sufficient to duplicate the process is made public more than a year before application is made. Halluin points out that an article in New Scientist on 25 October 1973, more than a year before the application was filed, gives a detailed report of Cohen's and Boyer's work from what was supposed to have been an off-the-record Gordon Conference.

Halluin is chairman of the Chemical

Practice Committee of the American Patent Law Association, and the chapter he contributed to the Cold Spring Harbor book - of which only a very minor part deals with the Stanford patent - was apparently written in this capacity and not as an employee of Exxon Research and Engineering.

A spokesman for Exxon said it does not plan to challenge the validity of the Stanford patent and is not even officially studying it. He said the reason Exxon had not joined with 73 other companies in buying a one-year licence to the patent (at a price of $\$ 10,000$ ) was that it had no plans to use the process commercially.

In spite of the rumour of a challenge to the patents, none has been filed, according to Rene Tegtmeyer, the US assistant commissioner for patents. Tegtmeyer said he could not elaborate on the reasons for the delay in the second patent, but said "it happens a couple of hundred times a year" that a patent examiner requests a reexamination in the light of new information. An explanation will probably come in two or three weeks, when a patent

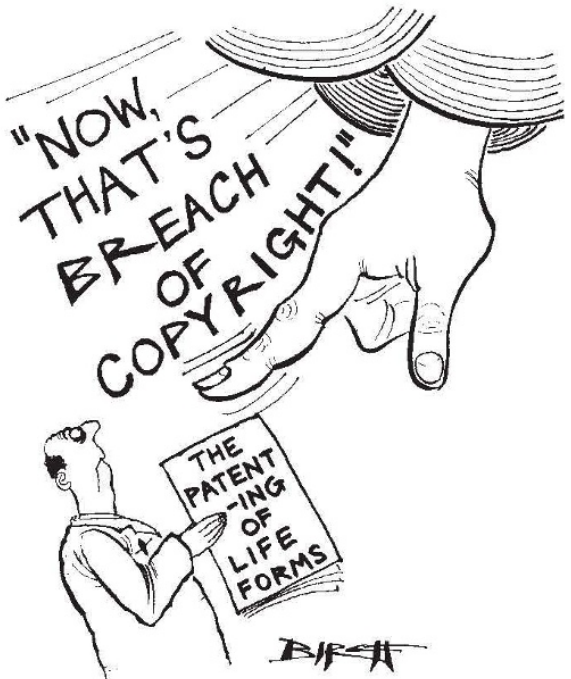

examiner is assigned to the reexamination. Normally, all such actions by the Patent Office are kept confidential. In this case, the applicant took the unusual step of opening its patent office file to public access.

Stanford's director of technology licensing, Niels Reimers, said that he was

\title{
Chemical weapons denied funds
}

\section{Washington}

The House of Representatives voted last week by a wide margin against the production of binary chemical weapons.

The 251-159 vote came on an amendment to the defence authorization bill which deletes $\$ 54$ million that the Reagan Administration had requested to begin production. The United States has not manufactured chemical weapons since 1969, when President Nixon ordered that production should be halted. The strength of congressional opposition to breaking that 13-year moratorium was evident when 81 Republicans broke ranks with the Administration and voted to block the funds.

The Administration wanted the new weapons as a counter to what it sees as evidence of increased Soviet production of chemical warfare agents and an increased willingness to use them. Opposition was led by Representative Clement Zablocki (Democrat, Wisconsin) and Representative Ed Bethune (Republican, Arkansas), the sponsors of the amendment, who managed to use the Administration's own argument against it. "We have an opportunity to demonstrate that we are not like the Soviets", Bethune said. "It just doesn't make sense to throw away the one shred of evidence that Americans truly yearn for the day when arms will be reduced." Zablocki argued further that to proceed with production would divide the NATO alliance, as the Europeans - with the possible exception of France - are opposed to having new chemical weapons on their soil. Opponents of production have argued that the new weapons are useless as a deterrent unless they are positioned in Europe.

The United States has a large stock of the older, unitary shells and bombs, which contain live nerve gas. Stocks are maintained in West Germany as well as the United States. The army says the binary weapons, which contain two relatively non-toxic gases that mix in flight to produce the nerve agent, are safer to store and to handle and are needed to replace deteriorating stocks of the older weapons.

The Senate, which in May approved the production of binary weapons by a close $49-45$ vote, is likely to accede to the House view when the two chambers confer on a final authorization bill. The House action does not affect the $\$ 705$ million that the Administration is requesting for further research and development on binary weapons and for chemical defence.

Congress last year authorized construction of a facility in Arkansas to produce the new weapons, but stopped short of authorizing production. According to Bethune, the House action this year may have been more a response to public pressure - which has apparently been heightened by reports of Soviet use of chemical weapons in Afghanistan and Soviet complicity in the "yellow rain" episodes in South East Asia - than a response to logic and reason. As one staff member said, "no one wants to get up and speak in favour of nerve gas".

Stephen Budiansky 